\title{
Leadership empowering behaviour, psychological empowerment, organisational citizenship behaviours and turnover intention in a manufacturing division
}

\author{
Authors: \\ Janie Bester ${ }^{1}$ \\ Marius W. Stander ${ }^{1}$ \\ Llewellyn E. van Zyl ${ }^{1}$ \\ Affiliations: \\ ${ }^{1}$ Optentia Research \\ Programme, North-West \\ University, Vanderbijlpark, \\ South Africa \\ Correspondence to: \\ Marius Stander \\ Email: \\ marius.stander@nwu.ac.za \\ Postal address: \\ PO Box 1174, Vanderbijlpark \\ 1900 , South Africa \\ Dates: \\ Received: 11 April 2014 \\ Accepted: 20 April 2015 \\ Published: 04 Aug. 2015 \\ How to cite this article: \\ Bester, J., Stander, M.W. \\ \& Van Zyl, L.E. (2015). \\ Leadership empowering \\ behaviour, psychological \\ empowerment, \\ organisational citizenship \\ behaviours and turnover \\ intention in a manufacturing \\ division. SA Journal of \\ Industrial Psychology/SA \\ Tydskrif vir Bedryfsielkunde, \\ 41(1), Art. \#1215, 14 pages. \\ http://dx.doi.org/10.4102/ \\ sajip.v41i1.1215

\section{Copyright:} \\ (c) 2015. The Authors. \\ Licensee: AOSIS \\ OpenJournals. This work is \\ licensed under the Creative \\ Commons Attribution \\ License.
}

Read online:
Orientation: Employees' perceptions of their leaders' behaviour play a role in creating empowering environments where employees are willing to do more than what is expected, with retention of employees as a result.

Research purpose: The aim of this study was to theoretically conceptualise and empirically determine the relationships between employees' perception of their leaders' empowering behaviour, psychological empowerment, organisational citizenship behaviours and intention to leave within a manufacturing division of an organisation.

Motivation for the study: In the ever-changing work environment, organisations must capitalise on their human capital in order to maintain competitiveness. It is therefore important to identify the role of employees' perception of leadership in contributing to the establishment of an environment where employees feel empowered, are willing to do more than what is expected and want to stay in the organisation.

Research design, approach and method: A non-experimental, cross-sectional survey design was used. The total population $(N=300)$ employed at the manufacturing division was targeted. Two hundred completed questionnaires were obtained. The Leader Empowering Behaviour Questionnaire, Measuring Empowerment Questionnaire, Organisational Citizenship Behaviour Questionnaire and Intention to Leave Scale were administered.

Main findings: Employees' perception of their leaders' empowering behaviour (keeping employees accountable, self-directed decision-making and people development), psychological empowerment (attitude and influence) and organisational citizenship behaviours (loyalty, deviant behaviour and participation) predict intention to leave the organisation.

Practical/managerial implications: Organisations should foster the elements of a positive organisation, in this case leader empowering behaviours, if they want to retain their employees.

Contribution/value-add: The results of this research contribute to scientific knowledge about the positive effects of employees experiencing their leaders as empowering.

\section{Introduction}

The concept of positive organisational behaviour and/or positive organisational scholarship has received much attention in recent years (Avey, Hughes, Norman \& Luthans, 2008; Cartwright \& Cooper, 2014). Positive organisations can be seen as focusing on the creation of overall wellness (Wilson, Dejoy, Vandenberg, Richardson \& McGrath, 2004) in an attempt to sustain individual and organisational performance (Cartwright \& Cooper, 2014). Components of this paradigm include leadership (Luthans, Youssef, Sweetman \& Harmse, 2013; Van Dierendonck \& Dijkstra, 2012; Youssef \& Luthans, 2012), empowerment (Avey et al., 2008; Van Dierendonck \& Dijkstra, 2012), organisational citizenship (Avey, Luthans \& Youssef, 2010; Chiang \& Hsieh, 2012; Paillé, 2013) and intention to stay within the organisation (Lam, Chen \& Takeuchi, 2009). Research suggests that these components are crucial for developing a competitive edge within the global market (Youssef \& Luthans, 2012).

Globalisation presents leaders with unique challenges and opportunities (Van Dierendonck \& Dijkstra, 2012; Youssef \& Luthans, 2012), which relies on employees' positive attitudes (Lavelle et al., 2009) towards their leaders' behaviour. Stander and Rothmann (2010) found that for South African organisations to cope with everlasting change, employees are required to build new competencies, resources and strategies in order to react proactively to the polarised demands and work roles of the new business environment. Therefore, organisations need to become more innovative in order to cope with various business demands to improve competitiveness 
(Taplin \& Winterton, 2007) through capitalising on employees' intelligence and creative thinking (Birt, Wallis \& Winternitz, 2004). Research suggests that leaders who encourage creative thinking stimulate the manifestation of various positive individual and organisational outcomes (Fong \& Snape, 2013), which in return cultivates a performance culture (Kontoghiorghes, 2014). This has led to a growing interest in understanding, predicting and developing empowerment and empowering leadership in research and practice (Kontoghiorghes, 2014; Van Dierendonck \& Dijkstra, 2012). It is postulated that employees' perceptions of their leaders may influence organisational and individual outcomes.

Kuokkanen and Leino-Kilpi (2000) and Menon (2001) categorise empowerment according to three approaches, namely structural empowerment, psychological empowerment and leadership empowerment. The structural approach involves entrusting power to others through effective listening, providing individuals with conditions to make them feel significant, emphasising teamwork and treating individuals equally, enabling employees throughout organisational ranks (Bish, Kenny \& Nay, 2014). When applied to leadership, this approach involves employees' perceptions of their leaders' behaviour that will enable them to participate in a higher level of decision-making, providing them an opportunity to take calculated risks by applying innovative thinking and / or problem-solving (Konczak, Stelly \& Trusty, 2000; Spreitzer, 1995; Van Dierendonck \& Dijkstra, 2012). Empowering leadership encourages and facilitates employees to lead and manage themselves (Tuckey, Bakker \& Dollard, 2012) and can thus be seen as a positive form of leadership.

The psychological approach to empowerment is based on the notion that empowerment relates to the perception of employees and the internal or cognitive processes that occur once structural and/or leadership empowerment has been implemented successfully (Fong \& Snape, 2013; Spreitzer, 1995). Fong and Snape (2013) suggest that empowerment could be viewed as a state that comes from within an individual, indicating that empowerment is similar to the concept of intrinsic motivation. Research suggests that empowering employees will result in the experience of positive work-related cognitions, which could result in increased employee satisfaction, loyalty, performance and service delivery (Bartram, Karimi, Leggat, \& Stanton, 2014; Stander \& Rothmann, 2010), as well as organisational citizenship (Raub \& Robert, 2010; Van Dijke, De Cremer, Mayer \& Van Quaquebeke, 2012) and willingness to stay with the organisation (Tuckey et al., 2012; Van Schalkwyk, Du Toit, Bothma, \& Rothmann, 2010). Therefore, leadership, and more specifically employees' experiences of their leaders as empowering, is at the core of psychological empowerment (Bartram et al., 2014).

\section{Leader empowering behaviour}

Suar, Tewari and Chaturbedi (2006) assert that the effective functioning of an organisation is reliant upon leadership that has the ability to influence tasks, strategies, organisational goals, beliefs, attitudes and behaviours of employees throughout a hierarchy. Further, a positive approach to leadership can leverage diverse strengths and capabilities and facilitate individual and organisational growth and development (Youssef \& Luthans, 2012). According to Peterson (2014), rapid change in functional work domains causes organisations to dispense traditional hierarchical position-based leadership models in order to implement structures where decision-making authority is stimulated at lower ranks within an organisation. For this to succeed, decision-makers need to be empowered by leaders (Van Dierendonck \& Dijkstra, 2012; Vecchio, Justin \& Pearce, 2010). Therefore, empowerment is practiced by leaders through providing employees with development opportunities to establish self-leadership skills, which could assist in the facilitation of positive responses to new roles and responsibilities (Kontoghiorghes, 2014; Spreitzer, Sutcliffe, Dutton, Sonenshein \& Grant, 2004). These leadership attitudes are clustered around the concept of leader empowering behaviour (MacPhee et al., 2014).

Leader empowering behaviours can be defined as a facilitative process where employees perceive their leaders to allow selfcontrol, self-regulation, self-management and self-leadership of employees (MacPhee et al., 2014; Vecchio et al., 2010). Empowering leaders will share information and delegate responsibility, encourage accountability, enable participative decision-making, coach, share information, lead by example, and show concern by listening and attending to followers (Arnold, Arad, Rhoades \& Drasgow, 2000; Spreitzer, 1995). Van Dierendonck and Dijkstra (2012) identified delegation of authority, accountability and facilitation (encouraging learning) as the core dimensions of empowering leader behaviour. Laschinger, Wong, McMahon, and Kaufmann (1999) claim that employees who have access to information and resources, as well as support from peers and superiors, and who is afforded the opportunity to learn and develop within the work environment are likely to experience feelings of empowerment. Brouer, Coleman-Gallagher, Sablynski and Wheeler (2007) suggest that empowering management practices create a sense of ownership amongst employees, which can relate to organisation-serving behaviours and reduced turnover intention. Several studies have demonstrated how empowering leadership leads to various outcomes, such as employee empowerment (Van Dierendonck\& Dijkstra, 2012; Zhang \& Bartol, 2010), employee engagement (Mendes \& Stander, 2011), commitment (Bordin, Bartram \& Casimir, 2007), job satisfaction (Bordin et al., 2007), role clarity (Mendes \& Stander, 2011), job insecurity (Van Schalkwyk et al., 2010), extra-role behaviours/organisational citizenship (Sanne, 2010; Van Dijke et al., 2012) and turnover intentions (Albrecht \& Andreetta, 2010; Chen, Sharma, Edinger, Shapiro \& Farh, 2011).

Recent studies found that employees' experiences of leader empowering behaviours are significantly positively related to the dimensions of psychological empowerment (Albrecht \& Andreetta, 2010; Chen et al., 2011; MacPhee et al., 2014). 
The environment provided by organisational leadership plays a key role in the psychological health and therefore the psychological experience of employees as well as the health of the organisation itself (Soonhee \& Wright, 2007; Spreitzer et al., 2004; Wilson et al., 2004).

\section{Psychological empowerment}

Conger and Kanungo (1988) were amongst the first to apply the motivational approach in conceptualising empowerment as the psychological motivation of people in the workplace. They claim that psychological empowerment is a process of enhancing employees' feelings of self-efficacy by identifying conditions within the workplace that foster feelings of powerlessness and removing them by means of both formal organisational practices and informal systems of providing efficacy information. Thomas and Velthouse (1990) build on the work of Conger and Kanungo (1988) by conceptualising empowerment as energy, instead of power, authority or capacity. In this sense, empowerment is not merely sharing authority to give more control over the environment or promoting feelings of self-efficacy, but more importantly, inspiring an employee to experience increased intrinsic task motivation. In Bandura's model (1989) of human agency, he suggests that humans are influenced by what they have perceived instead of the objective realities (Bandura, 1997). In keeping with this notion, Thomas and Velthouse (1990) state that employees' judgements about the observable organisational conditions are shaped by their subjective interpretations of reality.

Flowing from this, Spreitzer (1995) defines empowerment as a motivational construct manifested through four cognitions, namely, meaning (subjective assessment of one's job's importance); competence (personal sense of efficacy to perform a job with skill); self-determination (sense of control, autonomy and freedom of choice in initiating actions) and impact (one's ability to influence certain outcomes in the work environment). Together these cognitions reflect an employee's active orientation at work, in which he or she wishes to be and feel able to shape the work role and context. According to MacPhee et al. (2014), a psychological perspective on empowerment indicates that empowerment is a dynamic construct that reflects individual beliefs about the person-environment relationship. Chiang and Hsieh's (2012) research indicate that psychological empowerment significantly influences organisational citizenship behaviours, which impact on organisational performance.

\section{Organisational citizenship behaviours}

The process of motivating employees to perform beyond their job role has recently attracted researchers' attention (Paillé, 2013). Organisational citizenship behaviours are organisation-serving behaviours employees engage in that are of a discretionary nature and do not form part of their formal responsibilities (Wittig-Berman \& Lang, 1990). Various researchers assert that organisational citizenship behaviours are useful mechanisms that could promote organisational effectiveness that leads to improved performance (Ladebo, 2009; Mahembe \& Engelbrecht, 2014). Further, organisational citizenship behaviours are vital for organisational survival and effective organisational functioning because employees are willing to 'go the extra mile' (Lavelle, 2010; Paillé, 2013) in contributing toward achieving business goals. This can be classified as extra-role behaviours by employees (Raub \& Robert, 2010).

Various researchers assert that because of the discretionary nature of organisational citizenship, the construct can be classified as constructive, innovative and spontaneous behaviours (Ang \& Van Dyne, 1998; Hancer \& George, 2003; Kwantes, 2003; Wittig-Berman \& Lang, 1990). Organisational citizenship behaviours can be seen from both the individual and organisational perspectives (Lavelle, 2010). From an individual perspective, these behaviours may include employees assisting one another with tasks, supporting peers learning new tasks and replacing an absent colleague (Hancer \& George, 2003; Paillé, 2013). From an organisational perspective, these behaviours may include maintaining a favourable attitude toward the organisation, voluntary involvement in activities and defending the interest of the company (Hancer \& George, 2003; Paillé, 2013; WittigBerman \& Lang, 1990).

$\mathrm{Ng}$, Ke and Raymond (2014) argue that organisational citizenship behaviour is a global concept encompassing all positive organisationally relevant behaviours. This conceptualisation of organisational citizenship includes traditional in-role job performance behaviours, organisationally functional extra-role behaviours and political behaviours, such as active organisational participation (Bergeron, 2007). Van Dyne, Graham and Dienesch (1994) indicate that three interrelated categories can explain the organisation-serving behaviour syndrome, namely deviant behaviour, loyalty and participation. Deviant behaviour involves (dis)respect for orderly structures and processes. Loyalty involves serving the interests of the organisation and promoting its interest. Participation entails active and responsible involvement in interpersonal and social relations, being an internal change agent and contributing to organisational effectiveness (functional participation).

According to Engelbrecht and Chamberlain (2005), because organisational citizenship behaviours are not a formal enforceable requirement of an employee's work role or job description, it is viewed as an employee's personal choice. In support, organisational citizenship behaviours may be the first an employee withdraws in response to leader's behaviour. Withdrawing these organisational citizenship behaviours may threaten the internal health and reaction capabilities of an organisation (Ladebo, 2009).

Additionally, the experience of powerlessness, as a result of structural demands enforced by leadership, can lead to further withdrawal of organisational citizenship 
behaviours, which gives way to poor in-role performance that could lead to actual turnover (Coyle-Shapiro, 2002; Feather \& Rauter, 2004).

\section{Turnover intention}

Various authors argue that turnover has been a problematic area for management as it disrupts production schedules and becomes costly when new employees with appropriate skill sets need to be recruited, trained and brought up-to-date (Son, Kim \& Kim, 2014; Taplin \& Winterton, 2007). The issue of labour turnover becomes even more significant when key talent departs, especially during heightened competition and tight labour markets (Elanain, 2014; Kotzé \& Roodt, 2005; Truss, Mankin \& Kelliher, 2012). Furthermore, research suggests turnover intention is mitigated by perceived positive work features (Paillé, 2013). Similarly, Spreitzer et al. (2004) argue that positive work-related behaviours, linked to psychological empowerment and organisationserving behaviour, are a function of managerial attitudes (behaviours) as well as work structure which, in return, impacts on the turnover intention of employees (Mendes \& Stander, 2011).

Managing turnover intention is therefore imperative (Brewer \& Kovner, 2014; Elanain, 2014). From the perspectives of this research, turnover intention is defined as an employee's personal choice or decision to leave an organisation voluntarily to seek a more favourable or fulfilling position elsewhere (Brewer \& Kovner, 2014; Sjöberg \& Sverke, 2000). Turnover intentions are the most immediate determinants of the actual turnover behaviour within organisations (Ahmad \& Rainyee, 2014). These turnover intentions are associated with various individual and organisational factors (Ahmad \& Rainyee, 2014; Mendes \& Stander, 2011). Brouer et al. (2007) found that employees leave organisations to escape negative work environments, whilst other reasons are related to career goals and financially more attractive opportunities. Coincidently, voluntary turnover is an employee's personal choice and may be conceptualised as a mental consideration that is in comparison with alternative employment opportunities (Ahmad \& Rainyee, 2014; Mujtaba \& Udechukwu, 2007). Therefore, when an employee chooses to remain with an organisation, even under unsatisfying employment conditions, it is done with the goal to maintain a sense of status quo (Mujtaba \& Udechukwu, 2007).

\section{Relationship between employees' perceptions of leader empowering behaviour, psychological empowerment, organisational citizenship behaviours and intention to leave}

According to Mardanov, Heischmidt and Henson (2008), employee behaviour depends on the employee's perception of his or her relationship with the leader. Leader empowering behaviour, as experienced by the employee, is correlated with greater feelings of empowerment (Fong \& Snape, 2013; Greco, Laschinger \& Wong, 2006; Namasivayam, Guschait \& Lei, 2014) and results in positive employee attitude (Fong \& Snape, 2013). According to Avey et al. (2008), leadership style and psychological empowerment are related to feelings and cognitions of empowerment. Greasley et al. (2004) accentuate the leader's responsibility to assess the employee's perceived feelings of empowerment. Mendes and Stander (2011) postulate that it is essential to investigate the role of the leader as he or she has a significant influence on the employee's perception of empowerment.

Fong and Snape (2013) found that empowering leadership is associated with psychological empowerment whilst psychological empowerment is associated with organisational citizenship behaviour. Psychological empowerment and empowering leader behaviours may predict a variety of organisational citizenship behaviours (Coyle-Shapiro, 2002; Engelbrecht \& Chamberlain, 2005). Organisational citizenship behaviours impact positively on an individual's intention to stay (Avey et al., 2010; Coyne \& Ong, 2007; Lam et al., 2009). Unlike other researchers, Paille and Grima (2011) and Paille (2013) found an unexpected relationship between altruism as a dimension of citizenship and intention to leave. Their findings indicate that the higher the level of altruism, the more likely employees are to quit, whilst higher helping leads to intention to stay. Coyne and Ong (2007), Paillé and Grima (2011), as well as Paillé (2013) identified willingness to stay despite hardships as the most important form of organisational citizenship behaviour to explain turnover intention.

The manufacturing division discussed in this article focuses on continually strengthening a high-performance culture. At the time of the study, the division was undergoing changes (people, work processes and technology) in order to keep up with global demands. As a result of continuous pressure, it has become increasingly difficult for the division to attain organisational objectives and motivate and retain employees. Employees reported a lack of support, recognition and motivation by management. Employees described their work as less challenging whilst opportunities for development and involvement in decision-making were lacking. For leadership it has become critical to understand how the employees' perceptions of leadership will impact on employees' internal motivation (psychological empowerment) and willingness to go the extra mile (citizenship behaviours) in order to retain them. These challenges emphasised the need for an investigation of employee perception of leader empowering behaviour, psychological empowerment, organisational citizenship behaviour and intention to leave.

Previous research provides a solid foundation for the assumptions of this study. The assumption is that leader empowering behaviour is able to impact on psychological empowerment, which will affect employees' willingness to engage in extra-role activities (organisational citizenship behaviours) and essentially decrease employees' intentions to leave an organisation. As such the purpose of this study 
was to investigate the relationships between employees' perceptions of their leaders' empowering behaviour, psychological empowerment, organisational citizenship behaviours and intention to leave within a manufacturing division of an organisation.

Based on the above discussion, the following hypotheses were formulated:

H1: Practically and statistically significant relationships exist between leader empowering behaviour, psychological empowerment, organisational citizenship behaviours and turnover intention of employees.

H2: Leader empowering behaviour and psychological empowerment predict organisational citizenship behaviour.

H3: Leader empowering behaviour, psychological empowerment and organisational citizenship behaviours predict turnover intention.

\section{Research design Research approach}

A non-experimental cross-sectional correlational surveybased research design was used (Salkind, 2012) to determine the interrelationship between perceptions of leader empowering behaviour, psychological empowerment, organisational citizenship behaviours and turnover intention within a manufacturing division of an organisation. Salkind (2012) indicate that this research design is appropriate to sample behaviours, cognitions and affect at a current moment in time. This type of design is ideally suited to address the descriptive and predictive functions associated with a correlational design, in which relationships between variables are investigated (Shaughnessy, Zechmeister \& Zechmeister, 2003). However, no causal inferences can be established or inferred (Salkind, 2012).

\section{Participants}

An availability sample (Salkind, 2012) of employees working in a manufacturing division was drawn. A total population of 300 employees working within the manufacturing division of the organisation was targeted, and 200 usable questionnaires were obtained. Descriptive information of the sample is provided in Table 1.

The study population consisted of mainly Afrikaansspeaking (38.0\%) male employees $(67.0 \%)$ between the ages of 25 and 35 years (37.5\%). The majority of the sample had a Grade 12 level of education (43.5\%), had two to five years of service within the manufacturing division (30.5\%), and was permanently employed $(81.4 \%)$. The sample was representative of the actual population of the manufacturing division within the company.

\section{Measuring battery}

The Leader Empowering Behaviour Questionnaire (LEBQ) (Konczak et al., 2000) was used to measure employees'
TABLE 1: Characteristics of the participants.

\begin{tabular}{|c|c|c|c|}
\hline Item & Category & $f$ & $\%$ \\
\hline \multirow[t]{3}{*}{ Gender } & Male & 134 & 67.0 \\
\hline & Female & 64 & 32.0 \\
\hline & Missing values & 2 & 1.0 \\
\hline \multirow[t]{6}{*}{ Age } & 24 years and younger & 22 & 11.0 \\
\hline & $25-35$ years & 75 & 37.5 \\
\hline & $36-45$ years & 51 & 25.5 \\
\hline & $46-55$ years & 37 & 18.5 \\
\hline & 56 years and older & 14 & 7.0 \\
\hline & Missing values & 1 & 0.5 \\
\hline \multirow[t]{11}{*}{ Home language } & Afrikaans & 76 & 38.0 \\
\hline & English & 62 & 31.0 \\
\hline & SePedi & 4 & 2.0 \\
\hline & SeSotho & 27 & 13.5 \\
\hline & SeSwati & 0 & 0.0 \\
\hline & TshiVenda & 6 & 3.0 \\
\hline & IsiZulu & 13 & 6.5 \\
\hline & IsiNdebele & 1 & 0.5 \\
\hline & IsiXhosa & 10 & 5.0 \\
\hline & XiTsonga & 0 & 0.0 \\
\hline & Other & 1 & 0.5 \\
\hline \multirow{6}{*}{$\begin{array}{l}\text { Years of service in } \\
\text { organisation }\end{array}$} & Less than 1 year & 27 & 13.5 \\
\hline & $2-5$ years & 61 & 30.5 \\
\hline & $6-10$ years & 49 & 24.5 \\
\hline & $11-20$ years & 44 & 22.0 \\
\hline & More than 20 years & 18 & 8.5 \\
\hline & Missing values & 1 & 0.5 \\
\hline \multirow[t]{6}{*}{ Qualification level } & Grade 11 and lower & 35 & 17.5 \\
\hline & Grade 12 & 87 & 43.5 \\
\hline & Diploma/occupational certificates & 50 & 25.0 \\
\hline & Undergraduate degree & 17 & 8.5 \\
\hline & Postgraduate degree & 10 & 5.0 \\
\hline & Missing values & 1 & 0.5 \\
\hline \multirow[t]{4}{*}{ Job level } & Management & 33 & 16.5 \\
\hline & Specialist & 55 & 27.5 \\
\hline & Artisans and support staff & 102 & 51.0 \\
\hline & Missing values & 1 & 0.5 \\
\hline \multirow[t]{4}{*}{ Type of contract } & Permanent & 162 & 81.4 \\
\hline & Temporary & 27 & 13.5 \\
\hline & Fixed-term contract & 1 & 0.5 \\
\hline & Missing values & 1 & 0.5 \\
\hline \multirow[t]{3}{*}{ Department } & Production & 60 & 30.0 \\
\hline & Maintenance & 73 & 36.5 \\
\hline & Other & 67 & 33.5 \\
\hline
\end{tabular}

$f$, frequency.

perceptions of leader empowering behaviour. The instrument consists of 19 items, scored on a seven-point Likert scale ranging from 1 (strongly disagree) to 7 (strongly agree). The scale measures six dimensions of leader empowering behaviour: delegation of authority (3 items), accountability for outcomes (3 items), self-directed decision-making (3 items), information sharing (4 items), skills development (3 items) and coaching for innovative performance (3 items). 'My manager gives me the authority I need to make decisions that improve work processes and procedures' is an example of self-directed decision-making. The original instrument consisted of 17 items, but two items on information sharing were added from Arnold et al. (2000). These items are: 'My manager explains his or her decisions and actions to my work 
group' and 'My manager shares company goals to my work group'. Konczak et al. (2000) argues that a six-factor structure provides leadership with precise and detailed feedback and explains a greater percentage of the total variance. Konczak et al. (2000) report reliability coefficients that range between 0.82 and 0.88 . Higher scores indicate higher perceptions of leader empowering behaviours.

The Measuring Empowerment Questionnaire (MEQ) (Spreitzer, 1995) was utilised to measure the level of psychological empowerment experienced by employees. The items are scored on a seven-point Likert scale ranging from 1 (strongly disagree) to 7 (strongly agree). The scale consists of four subdimensions of psychological empowerment with three items each. Examples of items are "The work I do is very important to me' (meaning); 'I am confident about my ability to do my job' (competence); 'I can decide on my own how to go about doing my work' (self-determination) and 'My impact on what happens in my department is large' (impact). Spreitzer (1995) reports the following alpha coefficients for the subscales: 0.92 for meaning, 0.90 for competence, 0.85 for self-determination and 0.84 for impact, with an overall Cronbach alpha coefficient of 0.92. According to Spreitzer (1995), a four-factor structure explains a large percentage of the total variance of the instrument, which indicates the construct validity for the instrument.

The Organisational Citizenship Behaviour Questionnaire (OCBQ) (Van Dyne, Graham \& Dienesch, 1994) was used to measure the strength of employees' organisational citizenship behaviours in five dimensions, namely loyalty, deviant behaviour, social participation, advocacy participation and functional participation. A seven-point Likert scale, ranging from 1 (strongly disagree) to 7 (strongly agree), is used. High scores indicate strong citizenship behaviours (e.g. 'I try to represent the organisation favourably to outsiders' - loyalty). Van Dyne et al. (1994) report Cronbach alpha coefficients of 0.83 for deviant behaviour, 0.79 for loyalty, 0.68 for social participation, 0.84 for advocacy participation, 0.75 for functional participation and 0.91 for the entire 34-item organisational citizenship behaviour scale. According to Van Dyne et al. (1994) a five-factor structure explains a large percentage $(36 \%)$ of the total variance.

The Turnover Intention Scale (TIS) (Sjöberg \& Sverke, 2000) was used to measure turnover intention. The scale is a fivepoint Likert scale, ranging from 1 (strongly disagree) to 5 (strongly agree). The scale consists of three items; an example of an item is: 'If I was completely free to choose I would leave this job'. The Cronbach alpha coefficient for the TIS was 0.83 (Sjöberg \& Sverke, 2000). Principal component analysis of the TIS in this study supported a unifactorial solution explaining $74 \%$ of the variance. The component loadings varied from 0.73 to 0.94 (Sjöberg \& Sverke, 2000).

\section{Statistical analysis}

The SPSS program (SPSS, 2012) was employed to process the data. Exploratory factor analysis was performed to investigate the factor structure of measuring instruments. Descriptive statistics (e.g. means, standard deviations, skewness and kurtosis) were used to establish the normality of the distribution of scores. Cronbach alpha coefficients were used to determine the internal consistency of the four measuring instruments (Foxcroft \& Roodt, 2005).

Pearson correlation coefficients were used to specify the relationships between the variables. The significance level was set at $p<0.05$ (Field, 2007). Should a test statistic fall below 0.05, one can accept this as a sufficient amount of confidence to assume that the test statistic explains a great variation that is considered large enough to reflect what is genuinely taking place in the real population. Effect sizes were used to assess the practical significance of the correlation coefficients (Steyn, 2005). According to Field (2007), there are certain guidelines to assess the importance of an effect. Cutoff points of 0.30 (medium effect) and 0.50 (large effect) were set for practical significance of correlation coefficients (Field, 2007; Steyn, 2005).

A canonical correlation was used to determine the relationships between the two groups of constructs. The goal of the canonical correlation is to analyse the relationship between two sets of variables (Tabachnick \& Fidell, 2001). Hierarchical multiple regression analyses were conducted with the variables in their continuous form to determine whether leader empowering behaviour and psychological empowerment predict organisational citizenship behaviour and turnover intention. A regression analysis was used in order to determine the proportion of the total variance of one variable also explained by another (Moore, 1995).

\section{Results \\ Exploratory factor analyses}

An exploratory factor analyses was conducted to investigate the factor structure of the measuring instruments. Principal component analyses were used to assess the factorability of the items on the four measuring instruments. Eigenvalues (> 1) were used to determine the number of factors in each measuring instrument. Furthermore, a principal axis factoring with a direct oblimin rotation was used in cases where scales had more than two related factors.

Principal axis factoring with a direct oblimin rotation was used on the 19 items of the LEBQ. All items on the scale produced higher than recommended communalities $(>0.30)$. The principal axis factoring showed that three factors could be extracted, which explained $70.89 \%$ of the total variance of the scale. The scale produced communalities that were all higher than the suggested 0.30. The first factor was labelled 'development' (eigenvalue $=10.49$ ), which explained $55.26 \%$ of the total variance. The second factor was labelled 'self-directed decision-making' (eigenvalue = 1.94), which explained $10.23 \%$ of the total variance. Finally, the third factor was labelled 'accountability' (eigenvalue = 1.02), which explained a further $5.39 \%$ of the total variance. The results are in line with Van Dierendonck and Dijkstra 
(2012), who identified delegation of authority, accountability and facilitation (development) as the core dimensions of empowering leader behaviour.

Principal axis factoring with a direct oblimin rotation was also used on the 12 items of the MEQ. Analysis of eigenvalues $(>1)$ and scree plot indicated that two factors could be extracted which explains $78.16 \%$ of the total variance. The scale produced communalities that were all higher than the suggested 0.30 . The first factor was labelled 'attitude' (eigenvalue $=7.49$ ), which explained $62.42 \%$ of the total variance in the scale. The second factor was labelled 'influence' (eigenvalue $=1.89$ ), which explained a further $13.78 \%$ of variance in the scale. Influence is comprised of items relating to self-determination and impact. This supports the results of an earlier study with service employees by Fulford and Enz (1995), who called the 'new' factor 'influence'. Dimitriades (2005), Fulford and Enz (1995), Hancer and George (2003) and Kraimer, Seibert and Linden (1999) suggest that selfdetermination and impact have something in common that is not shared with the other dimensions of the questionnaire. In their study, Hancer and George (2003) report two factors which they call 'attitude' (meaning and competence) and 'influence' (self-determination and impact).

Principal axis factoring with a varimax rotation was conducted on the 34 items of the OCBQ. Analysis of eigenvalues $(>1)$ and scree plot indicated that three factors could be extracted which explains $48.35 \%$ of the total variance in the scale. The scale produced communalities that were all higher than the suggested 0.30. The first factor was labelled 'loyalty' (eigenvalue $=12.49$ ) and explained $35.59 \%$ of the total variance in the scale. The second factor was labelled 'deviant behaviour' (eigenvalue $=2.98$ ) and explained 7.40\% of the total variance in the scale. The final factor was labelled 'participation' (eigenvalue $=2.24$ ), which explained $5.73 \%$ of the total variance in the scale.

A principal axis factor analysis was conducted on the three items of the TIS. Analysis of eigenvalues $(>1)$ and scree plot indicated that one factor could be extracted, explaining a high percentage $(73.90 \%)$ of the total variance. The scale produced communalities that were all higher than the suggested 0.30 . The factor extracted specified mainly as turnover intention.

\section{Descriptive statistics and correlations}

Table 2 indicates that all the measures are sufficiently reliable $(\alpha>0.60)$ (Nunnally, 1978), with alpha values varying from 0.61 to 0.94 . Furthermore, the data on all the scales are normally distributed with skewness and kurtosis values smaller than 1.

Table 2 further indicates the correlation coefficients between the different variables. Development positively correlates practically significant (large effect) with attitude $(r=0.68$; $p<0.01)$, influence $(r=0.56 ; p<0.01)$, loyalty $(r=0.65$; $p<0.01)$ and participation $(r=0.74 ; p<0.01)$. Development has a practically significant negative relation with deviant behaviour $(r=-0.53$; $p<0.01)$ and a statistically significant negative relation with turnover intention $(r=-0.21 ; p<0.01)$.

Accountability positively correlates (practical large effect) with attitude $(r=0.73 ; p<0.01)$, influence $(r=0.50 ; p<0.01)$, loyalty $(r=0.69 ; p<0.01)$ and participation $(r=0.79 ; p<0.01)$ and negatively with deviant behaviour $(r=-0.61 ; p<0.01)$.

Self-directed decision-making positively correlates (practical large effect) with attitude $(r=0.57 ; p<0.01)$, influence $(r=0.85 ; p<0.01)$, loyalty $(r=0.58 ; p<0.01)$ and participation $(r=0.56 ; p<0.01)$. Self-directed decision-making negatively correlates statistically significantly with deviant behaviour $(r=-0.23 ; p<0.01)$ and turnover intention $(r=-0.22 ; p<0.01)$.

Attitude correlates practically significantly (large effect) with loyalty $(r=0.59 ; p<0.01)$ and participation $(r=0.87$; $p<0.01)$. Attitude negatively correlates practically and statistically significantly (large effect) with deviant behaviour $(r=-0.50 ; p<0.01)$. Attitude negatively correlates statistically significantly with turnover intention $(r=-0.14 ; p<0.01)$.

Influence correlates practically significantly (large effect) with loyalty $(r=0.56 ; p<0.01)$ as well as participation $(r=0.57 ; p<0.01)$ and statistically significantly negatively with deviant behaviour $(r=-0.17 ; p<0.01)$ and turnover intention $(r=-0.21 ; p<0.01)$.

Loyalty correlates statistically significantly with turnover intention $(r=0.23 ; p<0.01)$, deviant behaviour correlates statisticallysignificantlywithturnoverintention $(r=0.10)$ whilst

TABLE 2: Descriptive statistics, Cronbach's alpha coefficients, and correlation coefficients of the measuring instruments.

\begin{tabular}{|c|c|c|c|c|c|c|c|c|c|c|c|c|c|c|}
\hline Iten & & $\mathbf{M}$ & SD & Skewness & Kurtosis & $\alpha$ & 1 & 2 & 3 & 4 & 5 & 6 & 7 & 8 \\
\hline 1 & Development & 48.96 & 10.96 & -0.71 & -0.16 & 0.94 & - & - & - & - & - & - & - & - \\
\hline 2 & Accountability & 17.52 & 3.62 & -0.88 & -0.40 & 0.81 & $0.75^{* * \dagger}$ & - & - & - & - & - & - & - \\
\hline 3 & Self-directed decision-making & 34.75 & 9.56 & -0.57 & -0.35 & 0.92 & $0.68 * * \dagger$ & $0.64 * * \dagger$ & - & - & - & - & - & - \\
\hline 4 & Attitude & 35.11 & -1.19 & -0.99 & -0.69 & 0.93 & $0.68^{* * \dagger}$ & $0.73^{* * \dagger}$ & $0.57^{* * \dagger}$ & - & - & - & - & - \\
\hline 5 & Influence & 29.05 & 9.04 & -0.48 & -0.61 & 0.94 & $0.56^{* * \dagger}$ & $0.50^{* * \dagger}$ & $0.85 * * \dagger$ & $0.67 * * \dagger$ & - & - & - & - \\
\hline 6 & Loyalty & 53.81 & 11.63 & -0.33 & -0.53 & 0.92 & $0.65 * * \dagger$ & $0.69 * * \dagger$ & $0.58 * * \dagger$ & $0.59 * * \dagger$ & $0.56 * * \dagger$ & - & - & - \\
\hline 7 & Deviant behaviour & 31.28 & 14.14 & 0.58 & -0.61 & 0.81 & $-0.53 * * \dagger$ & $-0.61 * * \dagger$ & $-0.23 \dagger$ & $-0.50 * * \dagger$ & $-0.17 \dagger$ & $-0.51 * * \dagger$ & - & - \\
\hline 8 & Participation & 61.87 & 10.07 & -0.79 & -0.06 & 0.61 & $0.74 * * \dagger$ & $0.79 * * \dagger$ & $0.56^{* * \dagger} \dagger$ & $0.87^{* * \dagger}$ & $0.57 * * \dagger$ & $0.68^{* * \dagger}$ & $-0.63 * * \dagger$ & - \\
\hline 9 & Turnover intention & 8.16 & 3.52 & 0.34 & -0.71 & 0.82 & $-0.21 \dagger$ & 0.21 & $-0.22 \dagger$ & $-0.14 \dagger$ & $-0.21 \dagger$ & $0.23 \dagger$ & $0.10 \dagger$ & $-0.14 \dagger$ \\
\hline
\end{tabular}


participation negatively correlates statistically significantly with turnover intention $(r=-0.14 ; p<0.01)$.

\section{Multivariate statistics}

The relationships between the different variables were tested with canonical analysis. Shown in Table 3 are correlations between the variables and canonical variates, and standardised canonical variate coefficients. Within set variance accounted for the canonical variates ( $\%$ of variance), redundancies and canonical correlations between leader empowering behaviour, psychological empowerment, organisational citizenship behaviour and turnover intention set.

The results showed two statistically significant canonical variates. The Wilks-Lambada test of significance showed the results to be statistically significant $(p=0.00)$. According to Tabachnick and Fidell (2001), the significance should be taken at below 0.05 to indicate significance and reliability of the results. The first statistically significant canonical correlation was 0.91 with $82.92 \%$ overlapping variance. The first F-test $\left(\mathrm{F}_{(20,631)}=33.86 ; p>0.05\right)$ produced statistically

TABLE 3: Results of the canonical analysis: leader empowering behaviour, psychological empowerment, organisational citizenship behaviour and turnover intention.

\begin{tabular}{|c|c|c|c|c|}
\hline \multirow[t]{2}{*}{ Variable } & \multicolumn{2}{|c|}{ First canonical variate } & \multicolumn{2}{|c|}{ Second canonical variate } \\
\hline & Correlation & Coefficient & Correlation & Coefficient \\
\hline \multicolumn{5}{|l|}{ Outcomes set } \\
\hline Loyalty & -1.00 & -0.89 & 0.01 & -0.30 \\
\hline Deviant behaviour & 0.67 & 0.06 & 0.47 & 0.90 \\
\hline Participation & -0.74 & 0.10 & 0.26 & 0.76 \\
\hline Turnover intention & 0.11 & 0.02 & -0.56 & -0.67 \\
\hline $\begin{array}{l}\text { Percent of } \\
\text { variance }\end{array}$ & 41.38 & - & 5.08 & - \\
\hline Redundancy & 49.90 & - & 15.04 & - \\
\hline \multicolumn{5}{|l|}{ Antecedents set } \\
\hline Development & -0.83 & -0.24 & 0.22 & 0.25 \\
\hline Accountability & -0.89 & -0.35 & -0.16 & -1.01 \\
\hline $\begin{array}{l}\text { Self-directed } \\
\text { decision-making }\end{array}$ & -0.62 & 0.14 & 0.10 & 0.75 \\
\hline Attitude & -0.95 & -0.57 & 0.69 & -0.07 \\
\hline Influence & -0.63 & -0.05 & - & 0.46 \\
\hline Redundancy & 52.15 & - & 19.03 & - \\
\hline $\begin{array}{l}\text { Canonical } \\
\text { correlation }\end{array}$ & 0.91 & - & 0.58 & - \\
\hline
\end{tabular}

significant results. The second statistically significant canonical correlation was 0.58 with $33.81 \%$ overlapping variance. The second $F$-test $\left(F_{(12,505)}=11.74 ; p>0.05\right)$ produced statistically significant results. The third $F$-test $\left(F_{(6,384)}=8.08\right.$; $p>0.05)$ and fourth $F$-test $\left(F_{(2,193)}=6.84 ; p>0.05\right)$ were not statistically significant. According to Tabachnick and Fidell (2001), only canonical correlations with medium to high (>0.30) correlations should be interpreted.

The first canonical variate accounted for a more significant relationship between the different variates than the second canonical variate. Amongst the antecedent set, with a cut-off correlation of 0.30 (Tabachnick \& Fidell, 2001), development $(-0.83)$, accountability (-0.89), self-directed decision-making $(-0.63)$, attitude $(-0.59)$ and influence $(-0.63)$ correlated highly with the first canonical variate. In the antecedent set, loyalty (-1.00), deviant behaviour (0.67) and participation (-0.74) correlated with the first canonical variate. Only turnover intention (0.11) in the outcome set did not correlated with the first canonical variate. This implies that the first canonical variate indicates that higher levels of loyalty and higher levels of participation, coupled with lower levels of deviant behaviour, are associated with higher levels of development, accountability, self-directed decision-making, attitude and influence. In the second canonical variate, only deviant behaviour (0.47) and turnover intention (-0.56) were significantly related. The results provide sufficient evidence in support of Hypothesis 1.

\section{Multiple regressions}

Multiple regressions were conducted to determine the predictability of independent variables on the dependant variables. Table 4 summarises the results of the regression analysis.

Table 4 indicates the results of a multiple regression with loyalty as the dependent variable and leader empowering behaviours and psychological empowerment as the independent variables. The first step of the regression analysis produced a statistically significant model $\left(F_{(3,195)}=134.22\right.$; $p=0.00)$, which declares $67 \%$ of the total variance. Selfdirected decision-making $(\beta=0.35 ; t=5.22 ; p \leq 0.05)$ and accountability $(\beta=0.55 ; t=8.58 ; p \leq 0.05)$ made a statistically

TABLE 4: Multiple regression analysis with loyalty as dependent variable with leader empowering behaviour and psychological empowerment as independent variables.

\begin{tabular}{|c|c|c|c|c|c|c|c|c|c|c|}
\hline \multirow[t]{2}{*}{ Model } & \multirow[t]{2}{*}{ Variable } & \multicolumn{2}{|c|}{ Unstandardised coefficients } & \multirow{2}{*}{$\begin{array}{c}\text { Standardised coefficients } \\
\text { BETA }\end{array}$} & \multirow[t]{2}{*}{$t$} & \multirow[t]{2}{*}{$p$} & \multirow[t]{2}{*}{$F$} & \multirow[t]{2}{*}{$R$} & \multirow[t]{2}{*}{$R^{2}$} & \multirow[t]{2}{*}{$\Delta R^{2}$} \\
\hline & & B & SE & & & & & & & \\
\hline \multirow[t]{4}{*}{1} & (Constant) & 14.12 & 2.43 & - & 5.80 & 0.00 & 134.22 & 0.82 & 0.67 & 0.67 \\
\hline & Self-directed decision-making & 0.37 & 0.07 & 0.35 & 5.22 & 0.00 & - & - & - & - \\
\hline & Accountability & 1.76 & 0.21 & 0.55 & 8.58 & 0.00 & - & - & - & - \\
\hline & Development & -0.04 & 0.07 & -0.03 & -0.57 & 0.57 & - & - & - & - \\
\hline \multirow[t]{6}{*}{2} & (Constant) & 5.78 & 1.93 & - & 2.99 & 0.00 & 179.44 & 0.90 & 0.82 & 0.15 \\
\hline & Self-directed decision-making & 0.21 & 0.06 & 0.20 & 3.88 & 0.00 & - & - & - & - \\
\hline & Accountability & 0.85 & 0.18 & 0.27 & 4.65 & 0.00 & - & - & - & - \\
\hline & Development & -0.12 & 0.09 & -0.10 & -1.33 & 0.19 & - & - & - & - \\
\hline & Attitude & 0.97 & 0.10 & 0.59 & 10.04 & 0.00 & - & - & - & - \\
\hline & Influence & 0.02 & 0.09 & 0.02 & 0.23 & 0.82 & - & - & - & - \\
\hline
\end{tabular}

$*, p<0.05-$ statistically significant. 
TABLE 5: Multiple regression analysis with deviant behaviour as dependent variable with leader empowering behaviour and psychological empowerment as independent variables.

\begin{tabular}{|c|c|c|c|c|c|c|c|c|c|c|}
\hline \multirow[t]{2}{*}{ Model } & \multirow[t]{2}{*}{ Variable } & \multicolumn{2}{|c|}{ Unstandardised coefficients } & \multirow{2}{*}{$\begin{array}{c}\text { Standardised coefficients } \\
\text { BETA }\end{array}$} & \multirow[t]{2}{*}{$t$} & \multirow[t]{2}{*}{$p$} & \multirow[t]{2}{*}{$F$} & \multirow[t]{2}{*}{$R$} & \multirow[t]{2}{*}{$R^{2}$} & \multirow[t]{2}{*}{$\Delta R^{2}$} \\
\hline & & B & SE & & & & & & & \\
\hline \multirow[t]{4}{*}{1} & (Constant) & 74.52 & 3.77 & - & 19.75 & 0.00 & 57.34 & 0.69 & 0.47 & 0.47 \\
\hline & Self-directed decision-making & -0.46 & 0.111 & -0.35 & -4.11 & 0.00 & - & - & - & - \\
\hline & Accountability & -2.36 & 0.319 & -0.60 & -7.41 & 0.00 & - & - & - & - \\
\hline & Development & 0.59 & 0.109 & 0.40 & 5.38 & 0.00 & - & - & - & - \\
\hline \multirow[t]{6}{*}{2} & (Constant) & 76.98 & 4.04 & & 19.04 & 0.00 & 35.14 & 0.69 & 0.48 & 0.01 \\
\hline & Self-directed decision-making & -0.40 & 0.12 & -0.31 & -3.49 & 0.00 & - & - & - & - \\
\hline & Accountability & -2.00 & 0.38 & -0.51 & -5.23 & 0.00 & - & - & - & - \\
\hline & Development & 0.46 & 0.19 & 0.31 & 2.43 & 0.02 & - & - & - & - \\
\hline & Attitude & -0.34 & 0.20 & -0.17 & -1.70 & 0.09 & - & - & - & - \\
\hline & Influence & 0.18 & 0.19 & 0.11 & 0.92 & 0.36 & - & - & - & - \\
\hline
\end{tabular}

$*, p<0.05$ - statistically significant.

TABLE 6: Multiple regression analysis with participation as dependent variable with leader empowering behaviour and psychological empowerment as independent variables.

\begin{tabular}{|c|c|c|c|c|c|c|c|c|c|c|}
\hline \multirow[t]{2}{*}{ Model } & \multirow[t]{2}{*}{ Variable } & \multicolumn{2}{|c|}{ Unstandardised coefficients } & \multirow{2}{*}{$\begin{array}{c}\text { Standardised coefficients } \\
\text { BETA }\end{array}$} & \multirow[t]{2}{*}{$t$} & \multirow[t]{2}{*}{$p$} & \multirow[t]{2}{*}{$F$} & \multirow[t]{2}{*}{$R$} & \multirow[t]{2}{*}{$R^{2}$} & \multirow[t]{2}{*}{$\overline{\Delta R^{2}}$} \\
\hline & & B & SE & & & & & & & \\
\hline \multirow[t]{4}{*}{1} & (Constant) & 18.45 & 2.59 & - & 7.112 & 0.00 & 66.40 & 0.71 & 0.51 & 0.51 \\
\hline & Self-directed decision-making & 0.25 & 0.08 & 0.27 & 3.23 & 0.00 & - & - & - & - \\
\hline & Accountability & 0.95 & 0.22 & 0.34 & 4.35 & 0.00 & - & - & - & - \\
\hline & Development & 0.19 & 0.08 & 0.18 & 2.48 & 0.01 & - & - & - & - \\
\hline \multirow[t]{6}{*}{2} & (Constant) & 18.04 & 2.717 & - & 6.64 & 0.00 & 44.26 & 0.73 & 0.53 & 0.02 \\
\hline & Self-directed decision-making & 0.26 & 0.08 & 0.28 & 3.34 & 0.00 & - & - & - & - \\
\hline & Accountability & 1.10 & 0.26 & 0.40 & 4.27 & 0.00 & - & - & - & - \\
\hline & Development & -0.14 & 0.13 & -0.14 & -1.12 & 0.26 & - & - & - & - \\
\hline & Attitude & -0.08 & 0.14 & -0.05 & -0.56 & 0.58 & - & - & - & - \\
\hline & Influence & 0.40 & 0.13 & 0.36 & 3.06 & 0.00 & - & - & - & - \\
\hline
\end{tabular}

$*, p<0.05-$ statistically significant.

significant contribution to predicting loyalty. When psychological empowerment (attitude and influence) was entered into the second step of the regression, a statistically significant model was produced $\left(F_{(5,193)}=179.44 ; p=0.00\right)$. This model declared $82 \%$ of the total variance with self-directed decision-making $(\beta=0.20 ; t=3.88 ; p \leq 0.05)$, accountability $(\beta=0.27 ; t=4.65 ; p \leq 0.05)$ and attitude $(\beta=0.59 ; t=10.04 ;$ $p \leq 0.05)$ significantly contributing to the variance in loyalty.

Table 5 summarises the results of the regression analysis with deviant behaviour as the dependant variable with leader empowering behaviour and psychological empowerment as the independent variables. The first step of the regression analysisproducedastatisticallysignificantmodel $\left(F_{(3,195)}=57.34\right.$; $p=0.00)$ which declares $47 \%$ of the total variance. Selfdirected decision-making $(\beta=-0.35 ; t=-4.11 ; p \leq 0.05)$, accountability $(\beta=-0.60 ; t=-7.41 ; p \leq 0.05)$ and development $(\beta=0.40 ; t=5.38 ; p \leq 0.05)$ made a statistical significant contribution to the regression model. When psychological empowerment (attitude and influence) was entered into the second step of the regression a statistically significant model was produced $\left(F_{(5,193)}=35.14 ; p=0.00\right)$. This model declared $48 \%$ of the total variance. Self-directed decision-making $(\beta=-0.31 ; t=-3.49 ; p \leq 0.05)$, accountability $(\beta=-0.51 ; t=-5.23$; $p \leq 0.05)$ and development $(\beta=0.31 ; t=2.43 ; p \leq 0.05)$ significantly contributed to the variance in deviant behaviour.

Table 6 summarises the results of the regression analysis with participation as the dependant variable with leader empowering behaviour and psychological empowerment as the independent variables. The first step of the regression analysis produced a statistically significant model $\left(F_{(3,195)}=66.40 ; p=0.00\right)$, which declares $51 \%$ of the total variance. Moreover, self-directed decision-making $(\beta 0.27 ; t=3.23 ; p \leq 0.05)$, accountability $(\beta=0.34 ; t=4.35$; $p \leq 0.05)$ and development $(\beta=0.18 ; t=2.48 ; p \leq 0.05)$ predict participation. When psychological empowerment (attitude and influence) was entered into the second step of the regression, a statistically significant model was produced $\left(F_{(5,193)}=44.26 ; p=0.00\right)$. This model declared $53 \%$ of the total variance. Self-directed decision-making $(\beta=-0.28$; $t=3.34 ; p \leq 0.05)$, accountability $(\beta=0.40 ; t=4.27$; $p \leq 0.05)$ and influence $(\beta=0.36 ; t=3.06 ; p \leq 0.05)$ significantly contributed to the variance in participation. Resultantly, the results provide sufficient evidence in support of Hypothesis 2.

Table 7 summarises the results of the regression analysis with turnover intention as the dependant variable and leader empowering behaviour, psychological empowerment and organisational citizenship behaviour as the independent variables. The first step of the regression analysis produced a statistically significant model $\left(F_{(3,195)}=11.36 ; p=0.00\right)$, which declares $15 \%$ of the total variance. Self-directed decision-making $(\beta=-0.39 ; t=-3.60 ; p \leq 0.05)$, accountability $(\beta=0.48 ; t=4.64 ; p \leq 0.05)$ and development $(\beta=-0.26$; $t=2.77 ; p \leq 0.05)$ predict turnover intention. When psychological empowerment (attitude and influence) was 
TABLE 7: Multiple regression analysis with turnover intention as dependent variable with leader empowering behaviour, psychological empowerment and organisational citizenship behaviour as independent variables.

\begin{tabular}{|c|c|c|c|c|c|c|c|c|c|c|}
\hline \multirow[t]{2}{*}{ Model } & \multirow[t]{2}{*}{ Variable } & \multicolumn{2}{|c|}{ Unstandardised coefficients } & \multirow{2}{*}{$\begin{array}{c}\text { Standardised coefficients } \\
\text { BETA }\end{array}$} & \multirow[t]{2}{*}{$t$} & \multirow[t]{2}{*}{$p$} & \multirow[t]{2}{*}{$F$} & \multirow[t]{2}{*}{$R$} & \multirow[t]{2}{*}{$R^{2}$} & \multirow[t]{2}{*}{$\Delta R^{2}$} \\
\hline & & B & SE & & & & & & & \\
\hline \multirow[t]{4}{*}{1} & (Constant) & 9.45 & 1.19 & - & 7.96 & 0.00 & 11.36 & 0.39 & 0.15 & 0.15 \\
\hline & Self-directed decision-making & -0.13 & 0.03 & -0.39 & -3.60 & 0.00 & - & - & - & - \\
\hline & Accountability & 0.47 & 0.10 & 0.48 & 4.64 & 0.00 & - & - & - & - \\
\hline & Development & -0.10 & 0.03 & -0.26 & -2.77 & 0.01 & - & - & - & - \\
\hline \multirow[t]{6}{*}{2} & (Constant) & 10.40 & 1.27 & - & 8.20 & 0.00 & 7.74 & 0.41 & 0.17 & 0.02 \\
\hline & Self-directed decision-making & -0.10 & 0.04 & -0.33 & -2.91 & 0.00 & - & - & - & - \\
\hline & Accountability & 0.60 & 0.12 & 0.62 & 4.98 & 0.00 & - & - & - & - \\
\hline & Development & -0.14 & 0.06 & -0.38 & -2.34 & 0.02 & - & - & - & - \\
\hline & Attitude & -0.13 & 0.06 & -0.26 & -2.05 & 0.04 & - & - & - & - \\
\hline & Influence & 0.06 & 0.06 & 0.16 & 1.03 & 0.31 & - & - & - & - \\
\hline \multirow[t]{9}{*}{3} & (Constant) & 3.81 & 2.35 & - & 1.62 & 0.00 & 7.82 & 5.00 & 0.25 & 0.08 \\
\hline & Self-directed decision-making & -0.09 & 0.04 & -0.29 & -2.53 & 0.01 & - & - & - & - \\
\hline & Accountability & 0.67 & 0.13 & 0.68 & 5.20 & 0.00 & - & - & - & - \\
\hline & Development & -0.16 & 0.06 & -0.44 & -2.79 & 0.01 & - & - & - & - \\
\hline & Attitude & -0.02 & 0.08 & -0.03 & -0.21 & 0.83 & - & - & - & - \\
\hline & Influence & 0.00 & 0.06 & 0.01 & 0.07 & 0.94 & - & - & - & - \\
\hline & Deviant behaviour & -0.09 & 0.05 & -0.28 & -1.77 & 0.05 & - & - & - & - \\
\hline & Participation & 0.06 & 0.02 & 0.25 & 2.78 & 0.01 & - & - & - & - \\
\hline & Loyalty & 0.12 & 0.03 & 0.35 & 3.58 & 0.00 & - & - & - & - \\
\hline
\end{tabular}

$*, p<0.05-$ statistically significant.

entered into the second step of the regression a statistically significant model was produced $\left(F_{(5,193)}=7.74 ; p=0.00\right)$. This model declared $17 \%$ of the total variance. Self-directed decision-making $(\beta=-0.33 ; t=-2.91 ; p \leq 0.05)$, accountability $(\beta=0.62 ; t=0.98 ; p \leq 0.05)$, development $(\beta=-0.38 ; t=-2.34 ;$ $p \leq 0.05)$ and influence $(\beta=0.16 ; t=1.03 ; p \leq 0.05)$ significantly contributed to the variance in turnover intention. As organisational citizenship behaviours (loyalty, deviant behaviour and participation) was entered into the third step of the regression, a statistically significant model was produced $\left(F_{(8,190)}=7.82 ; p=0.00\right)$. This model declared $25 \%$ of the total variance. Self-directed decision-making $(\beta=-0.09 ; t=-2.53 ; p \leq 0.05)$, accountability $(\beta=0.67$; $t=5.20 ; p \leq 0.05)$, development $(\beta=-0.16 ; t=-2.79 ; p \leq 0.05)$, loyalty $(\beta=-0.09 ; t=-1.77 ; p \leq 0.05)$, deviant behaviour $(\beta=0.06 ; t=2.78 ; p \leq 0.05)$ and participation $(\beta=0.12$; $t=3.58 ; p \leq 0.05)$ significantly contributed to the variance in turnover intention. Resultantly, the results provide sufficient evidence in support of Hypothesis 3.

\section{Discussion}

The main objective of this study was to examine the relationship between leader empowering behaviour, psychological empowerment, organisational citizenship behaviour and turnover intention within the manufacturing division of an organisation. It was found that leader empowering behaviour (development, accountability and self-directed decisionmaking), psychological empowerment (attitude and influence) and organisational citizenship behaviour (loyalty, deviant behaviour and participation) were statistically and practically significantly interrelated with effect sizes ranging from medium to large. The results provided evidence that leader empowering behaviour and psychological empowerment could predict organisational citizenship behaviour. The results also proved that leader empowering behaviour, psychological empowerment and organisational citizenship behaviours act as predictors for turnover intention within the manufacturing division of the organisation.

\section{Hypothesis 1}

Pearson correlations indicated that the three components of leader empowering behaviour were practically significantly related to the components of psychological empowerment and organisational citizenship behaviour. However, deviant behaviour (as a component of organisational citizenship behaviour) negatively related practically significantly to development and accountability, and statistically significantly to self-directed decision-making. Similarly, Pearson correlations indicated practically significant relationships between the components of psychological empowerment (attitude and influence) and organisational citizenship behaviours as well as statistically significantly with turnover intention. This implies that enhancing the perceptions of psychological empowerment amongst employees will result in generating organisational citizenship behaviours amongst employees, which will decrease their intention to leave the manufacturing division.

Employees that experience their leader to invest in their development, encourage accountability, enable participative decision-making and lead by example would be more inclined to experience psychological empowerment within this context (Mendes \& Stander, 2011). This would result in an increase in levels of loyalty towards the organisation and participation in organisational processes. These individuals may be less inclined to engage in deviant work behaviour. Employees will be less inclined to miss deadlines or stay away from work. Higher levels of loyalty and higher levels of participation, coupled with lower levels of deviant behaviour, are associated with higher levels of development, 
indicating that leaders can influence extra-role behaviour by developing direct reports. These results are consistent with various other studies examining the relationship between the variables (Chiang \& Hsieh, 2012; Engelbrecht \& Chamberlain, 2005).

The results denote that leadership empowerment behaviour should be encouraged throughout the organisational structures, which should result in decreased levels of turnover intention and increased levels of psychological empowerment and organisational citizenship behaviour. Within this context, managers should aim to develop and grow leadership throughout the division by incorporating empowering behaviours in their leadership styles. In support, Konczak et al. (2000) state that the leader of the future should tune into the environment by sensing the need for opportunity; engaging in kaleidoscope thinking by challenging assumptions to create new opportunities; encouraging follower buy-in by communicating inspiring visions; develop a dream by nurturing working teams; mastering perseverance and building coalitions and heroes by sharing credit and recognition with followers through the development of skills and competencies.

\section{Hypothesis 2}

The results indicate that when a leader invests in the development of his or her employees, allows for decisionmaking and keeps employees accountable, they will experience feelings of psychological empowerment, which may lead to a willingness to be more loyal, participate in extra-role activities and be obedient to the organisation. These findings are in line with established literature (see Albrecht \& Andreetta, 2010; Chen et al., 2011; Raub \& Robert, 2010; Van Dijke et al., 2012; Zhang \& Bartol, 2010).

Leader empowering behaviour and psychological empowerment showed to predict organisational citizenship behaviour within this sample. Self-directed decisionmaking, accountability and attitude significantly contributed to the variance in loyalty. When employees feel they are in control of their work environment, they tend to find more meaning in what they do. This will result in feelings of confidence and competence, which leads to being committed and loyal towards the organisation. All the leadership empowerment constructs contributed to the variance in deviant behaviour. This implies that, when leaders empower their people (as experienced by subordinates), employees will be more willing to follow rules and procedures and produce high-quality work. Self-directed decision-making, accountability and influence significantly contributed to the variance in participation, implying that leaders who create feelings of self-determination and having an impact on the work environment (as experienced by the employees) will experience a higher level of participation from their people (Chen et al., 2011). Employees will contribute more to workrelated matters, help co-workers and focus on continuous improvements (Zhang \& Bartol, 2010).

\section{Hypothesis 3}

Finally, a three-stage regression analysis was used to determine the predictive capacity of leadership empowering behaviour, psychological empowerment and organisational citizenship behaviour on employees' turnover intention within the manufacturing division. Self-directed decision-making, accountability, development, loyalty, deviant behaviour and participation significantly contributed to the variance in turnover intention. The leader's ability to empower people (as experienced by subordinates) may ensure willingness of employees to become involved in in-role job performance and extra-role behaviours, preferring to stay with the organisation, even in times of difficulties. The results of this research support previous studies that indicated that a positive approach to leadership (Avey et al., 2008; Luthans, Yousef, Sweetman \& Harmse, 2013; Van Dierendonck \& Dijkstra, 2012; Youssef \& Luthans, 2012) leads to empowerment (Avey et al., 2007; Van Dierendonck \& Dijkstra, 2012), organisational citizenship (Avey et al., 2006; Chiaburu \& Byrne, 2009; Chiang \& Hsieh, 2012; Lavelle, 2010; Paillé, 2013) and intentions to stay within the organisation (Lam et al., 2009).

Further, the results indicate that in order for organisational talent to be retained, leadership throughout the division's structures should strive to increase employees' feelings of self-efficacy. Employees should therefore be provided with a meaningful work experience by allowing them to gain the competence and skill they require to feel competent enough to take initiative in solving problems without supervision. By focusing on a positive approach to leadership and leadership development, organisations can contribute to employees' experiences associated with psychological empowerment and resulting in organisational citizenship behaviours. Similarly, it could also affect the longevity of the organisation by lowering staff turnover intentions.

\section{Limitations and recommendations for future research}

The use of a cross-sectional survey and the use of an availability sample merely provide a representation of employees' opinions, thoughts, feelings and/or perceptions at one point in time. As such, causal factors associated with these subjective experiences cannot be isolated nor can their effect on the results be interpreted (Salkind, 2012). The sample size obtained limits the type of statistical analyses that could be used (e.g. structural equation modelling vs. multiple regression analysis). As a result, the current analysis procedure does not account for all the variance amongst constructs and therefore limits the extent of the research. Another limitation of the study is that the measurements were based on selfreporting methods. Self-report measures are subjective in nature and are influenced by how an employee feels at a specific point in time. These feelings might not be an accurate reflection of the entire system at the given time. The findings of the study population obtained might not be generalised because of the relatively small sample of employees in the manufacturing division. 
Regardless of the study's shortcomings, the findings obtained offer valuable proactive suggestions for future research. For the study to have a greater impact, it should be stressed that the findings obtained should be replicated with larger samples forming part of the manufacturing division in order to draw more valid and reliable factor-structures for the LEBQ, MEQ and OCBQ within the South African context.

It is further recommended that a longitudinal study is conducted to establish more valid and reliable levels of leadership empowerment behaviour, psychological empowerment, organisational citizenship behaviour and turnover intention of the study population over a period of time rather than obtaining one set of perspectives, attitudes and opinions at a certain point in time, which can limit the recommendations and outcomes of the study.

Future research might explore the implications of the multidimensionality of organisational citizenship behaviour. It was found that although the three categories of organisational citizenship behaviour are correlated, employees may choose not to engage equally in all forms of citizenship behaviour. Future research should also examine when and what conditions are necessary for certain forms of organisational citizenship behaviour to occur in order to gain a better understanding of what restricts the practice of such behaviours.

\section{Acknowledgements}

'Death ends a life, not a relationship.' - Mitch Albom (2009, p. 190).

This work is dedicated to the loving memory of our departed student, colleague and friend. Your presence lingers in our hearts and minds.

Janie Bester (1985-2010)

You are truly missed.

\section{Competing interests}

The authors declare that they have no financial or personal relationships which may have inappropriately influenced them in writing this article.

\section{Authors' contributions}

This article is based on the work of J.B. (North-West University) carried out as part of her master's dissertation. J.B. passed away before completion of the project. This article was completed on her behalf by M.S. (North-West University) and L.E.v.Z. (North-West University).

\section{References}

Ahmad, A., \& Rainyee, R.A. (2014). Which is the better predictor of employee turnover intentions: Job satisfaction or organizational commitment? A literature review. Business and Management, $6(1), 74-81$.
Albom, M. (2009). Tuesdays with Morrie: An old man, a young man, and life's greatest lesson. London, UK: Hachette.

Albrecht, S., \& Andreetta, M. (2010). The influence of empowering leadership, empowerment and engagement on affective commitment and turnover intentions in community health service workers: Test of a model. Leadership in Health Services, 24(3), 228-237. http://dx.doi.org/10.1108/ 17511871111151126

Ang, S., \& Van Dyne, L. (1998). Organizational citizenship behavior of contingent workers in Singapore. Academy of Management Journal, 41(6), 692-703. http:// dx.doi.org/10.2307/256965

Arnold, J.A., Arad, S., Rhoades, J.A., \& Drasgow, F. (2000). The empowering leadership questionnaire: The construction and validation of a new scale for measuring leader behaviours. Journal of Organisational Behaviour, 21, 249-269. http://dx.doi. org/10.1002/(SICI)1099-1379(200005)21:3\%3C249::AID-JOB10\%3E3.0.CO;2-

Avey, J.B., Hughes, L.W., Norman, S.M., \& Luthans, K.W. (2008). Using positivity, transformational leadership and empowerment to combat employee negativity. Leadership \& Organization Development Journal, 29(2), 110-126. http://dx doi. org/10.1108/01437730810852470

Avey, J.B., Luthans, F., \& Youssef, C.M. (2010). The additive value of positive psychological capital in predicting work attitudes and behaviors. Journal of Management, 36(2), 430-452. http://dx.doi.org/10.1177/0149206308329961

Bandura, A. (1989). Human agency in social cognitive theory. American psychologist, 44(9), 1175. http://dx.doi.org/10.1037/0003-066X.44.9.1175

Bandura, A. (1997). Self-efficacy: Toward a unifying theory of behavioural change. Psychological Review, 84, 191-215. http://dx.doi.org/10.1037/0033295X.84.2.191

Bartram, T., Karimi, L., Leggat, S.G., \& Stanton, P. (2014). Social identification: Linking high performance work systems, psychological empowerment and patient care. The International Journal of Human Resource Management, 25(17), 2401-2419. http://dx.doi.org/10.1080/09585192.2014.880152

Bergeron, D.M. (2007). The potential paradox of organizational citizenship behavior: Good citizens at what cost? Academy of Management Review, 32(4), 1078-1095. http://dx.doi.org/10.5465/AMR.2007.26585791

Birt, M., Wallis, T., \& Winternitz, G. (2004). Talent retention in a changing workplace: An investigation of variables considered important to South African talent. South African Journal of Business Management, 35(2), 25-31.

Bish, M., Kenny, A., \& Nay, R. (2014). Perceptions of structural empowerment: Nurse leaders in rural health services. Journal of Nursing Management, 22(1), 29-37. http://dx.doi.org/10.1111/jonm.12029

Bordin, C., Bartram, T., \& Casimir, G. (2007). The antecedents and consequences of psychological empowerment among Singaporean IT employees. Management Research News, 30(1), 34-46. http://dx.doi.org/10.1108/01409170710724287

Brewer, C.S., \& Kovner, C.T. (2014). Intersection of migration and turnover theories What can we learn? Nursing Outlook, 62(1), 29-38. http://dx.doi.org/10.1016/j. outlook.2013.09.002

Brouer, R.L., Coleman-Gallagher, V., Sablynski, C.J., \& Wheeler, A.R. (2007). When person-organization (mis)fit and (dis)satisfaction lead to turnover: The moderating role of perceived job mobility. Journal of Managerial Psychology, 22(2), 203-219. http://dx.doi.org/10.1108/02683940710726447

Cartwright, S., \& Cooper, C.L. (2014). Towards organizational health: Stress, positive organizational behavior, and employee well-being. In S. Cartwright \& C.L. Cooper (Eds.). Bridging occupational, organizational and public health (pp. 29-42). Amsterdam: Springer. http://dx.doi.org/10.1007/978-94-007-5640-3_3

Chen, G., Sharma, P.N., Edinger, S.K., Shapiro, D.L., \& Farh, J-L. (2011). Motivating and demotivating forces in teams: Cross-level influences of empowering leadership and relationship conflict. Journal of Applied Psychology, 96(3), 541-557. http:// dx.doi.org/10.1037/a0021886

Chiaburu, D.S. \& Byrne, Z.S. (2009). Predicting OCB role definitions: Exchanges with the organization and psychological attachment. Journal of Business and Psychology, 24(2), 201-214. http://dx.doi.org/10.1007/s10869-009-9100-x

Chiang, C-F., \& Hsieh, T-S. (2012). The impacts of perceived organizational support and psychological empowerment on job performance: The mediating effects of organizational citizenship behavior. International Journal of Hospitality Management, 31, 180-190. http://dx.doi.org/10.1016/j.ijhm.2011.04.011

Conger, J.A., \& Kanungo, R.N. (1988). The empowerment process: Integrating theory and practice. Academy of Management Review, 13, 471-482. http://dx.doi. org $/ 10.2307 / 258093$

Coyle-Shapiro, J. (2002). A psychological contract perspective on organisational citizenship behavior. Journal of Organizational Behavior, 23(8), 927-946.

Coyne, I., \& Ong, T. (2007). Organizational citizenship behaviour and turnover intention: A cross-cultural study. The International Journal of Human Resource Management, 18(6), 1085-1097. http://dx.doi.org/10.1080/09585190701321831

Dewettinck, K., Singh, J., \& Buyens, D. (2003). Psychological empowerment in the workplace: reviewing the empowerment effects on critical work outcomes. Vlerick Workplace: reviewing the empowerment effects on critical work outcomes. Vlerick Leuven Gent Working Paper Series 2003/29. Retrieved January 10, 2014 from http://www.vlerick.be/en/2
vlgms-wp-2003-29.pdf

Dimitriades, Z.S. (2005). Employee empowerment in the Greek context. International Journal of Manpower, 26(1), 80-92. http://dx.doi.org/10.1108/ 01437720510587299

Elanain, H.M.A. (2014). Leader-member exchange and intent to turnover: Testing a mediated-effects model in a high turnover work environment. Management Research Review, 37(2), 110-129. http://dx.doi.org/10.1108/MRR-09-20120197 
Engelbrecht, A.S., \& Chamberlain, L. (2005). The influence of transformational leadership on organisational citizenship behaviour through justice and trust. Management Dynamics: Journal of the Southern African Institute for Management Management Dynamics:
Scientists, 14(1), 2-15.

Feather, N.T., \& Rauter, K.A. (2004). Organizational citizenship behavior in relation to the job status, job insecurity, organizational commitment and identification, job satisfaction and work values. Journal of Occupational and Organizational job satisfaction and work values. Journal of Occupational and Organizat
Psychology, 77, 81-94. http://dx.doi.org/10.1348/096317904322915928

Field, A. (2007). Discovering statistics using SPSS. Thousand Oaks: Sage.

Fong, K.H., \& Snape, E. (2013). Empowering leadership, psychological empowerment and employee outcomes: Testing a multi-level mediating model. British Journal of Management. http://dx.doi.org/10.1111/1467-8551.12048

Foxcroft, C., \& Roodt, G. (2005). An introduction to psychological assessment in the South African context (2nd edn). Cape Town: Oxford University Press.

Fulford, M., \& Enz, C. (1995). The impact of empowerment on service employees. Journal of Managerial Issues, 7(2), 161-175.

Greasley, K., Bryman, A., Dainty, A., Price, A., Soetanto, R., \& King, N. (2005). Employee org/10.1108/01425450510605697

Greco, P., Laschinger, H.K.S., \& Wong, C. (2006). Leader empowering behaviours, staff nurse empowerment and work engagement/burnout. Nursing Leadership, 19, 41-56. http://dx.doi.org/10.12927/cjnl.2006.18599

Hancer, M., \& George, R.T. (2003). Psychological empowerment of non-supervisory employees working in full-service restaurants. International Journal of Hospitality Management, 22, 3-16. http://dx.doi.org/10.1016/S0278-4319(02)00032-4

Konczak, L.J., Stelly, D.J., \& Trusty, M.L. (2000). Defining and measuring empowerment leader behaviours: Development of an upward feedback instrument. Educational and Psychological Measurement 60, 301-313. http://dx.doi.org/10.1177/ 00131640021970420

Kontoghiorghes, C. (2014). Transfer of learning in organizations. New York: Springer.

Kotzé, K., \& Roodt, G. (2005). Factors that affect the retention of managerial and specialist staff: An exploratory study of an employee commitment model. South African Journal of Human Resource Management, 3(2), 48-55. http://dx.doi. African Journal of Human
org/10.4102/sajhrm.v3i2.65

Kraimer, M.L., Seibert, S.E. \& Linden, R.C. (1999). Psychological empowerment as a multidimensional construct:Atest of construct validity. Educationaland Psychological Measurement, 59, 127-142. http://dx.doi.org/10.1177/0013164499591009

Kuokkanen, L., \& Leino-Kilpi, H. (2000). Power and empowerment in nursing: Three theoretical approaches. Journal of Advanced Nursing, 31, 235-241. http://dx.doi. org/10.1046/j.1365-2648.2000.01241.x

Kwantes, C.T. (2003). Organizational citizenship and withdrawal behaviors in the USA and India: Does commitment make a difference? International Journal of Cross CulturalManagement, 3, 5-26. http://dx.doi.org/10.1177/1470595803003001847

Ladebo, O.J. (2009). Emotional exhaustion and strain reactions: Perceived organisational support as moderator. South African Journal of Psychology, 39(1) 46-58. http://dx.doi.org/10.1177/008124630903900104

Lam, W., Chen, Z., \& Takeuchi, N. (2009). Perceived human resource management practices and intention to leave of employees: The mediating role of organizationa citizenship behavior in a Sino-Japanese joint venture. The Internationa Journal of Human Resource Management, 20(11), 2250-2270. http://dx.doi org/10.1080/09585190903239641

Laschinger, H.K.S., Wong, C., McMahon, L., \& Kaufmann, C. (1999). Leader behavior impact on staff nurse empowerment, job tension, and work effectiveness. Journa of Nursing Administration, 29(5), 28-39. http://dx.doi.org/10.1097/00005110199905000-00005

Lavelle, J.J. (2010). What motivates OCB? Insights from the volunteerism literature. Journal of Organizational Behavior, 31, 918-923. http://dx.doi.org/10.1002/ job.644

Lavelle, J.J., Brockner, J., Konovsky, M.A., Price, K.H., Henley, A.B., Taneja, A., \& Vinekar, V. (2009). Commitment, procedural fairness, and organizational citizenship behavior: A multifoci analysis. Journal of Organizational Behavior, 30, 337-357. behavior: A multifoci analysis. Jou
http://dx.doi.org/10.1002/job.644

Luthans, F., Youssef, C.M., Sweetman, D.S., \& Harmse, P.D. (2013). Meeting the leadership challenge of employee well-being through relationships PsyCap and health Psycap. Journal of Organisational Studies, 20(1), 118-133. http://dx.doi. org/10.1177/1548051812465893

MacPhee, M., Dahinten, V.S., Hejazi, S., Laschinger, H., Kazanjian, A., McCutcheon A., Skelton-Green, J., \& O'Brien-Pallas, L. (2014). Testing the effects of an empowerment-based leadership development programme: Part 1 - Leader outcomes. Journal of Nursing Management, 22(1), 4-15. http://dx.doi. org/10.1111/jonm.12053

Mahembe, B., \& Engelbrecht, A.S. (2014). The relationship between servan leadership, organisational citizenship behaviour and team effectiveness. $S A$ Journal of Industrial Psychology, 40(1), Art. \#1107, 10 pages. http://dx.doi. org/10.4102/sajip.v40i1.1107

Mardanov, I.S., Heischmidt, K., \& Henson, A. (2008). Leader-member exchange and job satisfaction bond and predicted employee turnover. Journal of Leadership and Organisational Studies, 15(2), 159-175. http://dx.doi org/10.1177/1548051808320985

Mendes, F., \& Stander, M.W. (2011). Positive organisation: The role of leade behaviour in work engagement and retention. SA Journal of Industrial Psychology 37(1), 1-13. http://dx.doi.org/10.4102/sajip.v37i1.900

Menon, S.T. (2001). Employee empowerment: An integrative psychological approach. Applied Psychology: An International Review, 50, 153-180. http://dx.doi. org/10.1111/1464-0597.00052
Moore, D.S. (1995). The basic practice of statistics. New York: Freeman.

Mujtaba, B.G., \& Udechukwu, I.I. (2007). Determining the probability that an employee will stay or leave the organization: A mathematical and theoretical model for organizations. Human Resource Development Review, 6(2), 164-184. http://dx.doi.org/10.1177/1534484307300239

Namasivayam, K., Guchait, P., \& Lei, P. (2014). The influence of leader empowering behaviors and employee psychological empowerment on customer satisfaction. International Journal of Contemporary Hospitality Management, 26(1), 69-84. http://dx.doi.org/10.1108/IJCHM-11-2012-0218

Ng, S.M., Ke, G.N., \& Raymond, W. (2014). The mediating role of work locus of control on the relationship among emotional intelligence, organisational citizenship behaviours, and mental health among nurses. Australian Journal of Psychology, 66(4), 207-215. http://dx.doi.org/10.1111/ajpy.12049

Nunnally, J. (1978). Psychometric theory. New York: McGraw Hill.

Paille, P. (2013). Organizational citizenship behavior and employee retention: How important are turnover cognitions? The International Journal of Human Resource Management, 24(4), 768-790. http://dx.doi.org/10.1080/09585192. 2012.697477

Paillé, P., \& Grima, F. (2011). Citizenship and withdrawal in the workplace: Relationship between organizational citizenship behavior, intention to leave current job and intention to leave the organization. The Journal of Social Psychology, 151(4), 478-493. http://dx.doi.org/10.1080/00224545.2010. 507266

Peterson, N.A. (2014). Empowerment theory: Clarifying the nature of higher-order multidimensional constructs. American Journal of Community Psychology, 53(1), 96-108. http://dx.doi.org/10.1007/s10464-013-9624-0

Raub, S., \& Robert, C. (2010). Differential effects of empowering leadership on inrole and extra-role employee behaviors: Exploring the role of psychological empowerment and power values. Human Relations, 63(11), 1743-1770. http:// dx.doi.org/10.1177/0018726710365092

Salkind, N.J. (2012). Exploring research. (8th edn). Salt River: Pearson.

Sanne, S. (2010). Empower the similar ones: Perceived leader-follower similarity moderates empowering leadership effects on citizenship performance. Retrieved January 10, 2014, from http://www.sebastian-sanne.com/storage/ Empower\%20the \%20Similar\%20Ones\%20-\%20Sanne\%20Kerschreiter\%20 Frey\%202010.pdf

Shaughnessy, J.J., Zechmeister, E.B., \& Zechmeister, J.S. (2003). Research methods in psychology (6th edn.). New York: McGraw-Hill.

Sjöberg, A., \& Sverke, M. (2000). The interactive effect of job involvement and organisational commitment on job turnover revisited: A note on the mediating role of turnover intention. Scandinavian Journal of Psychology, 3, 247-252. http://dx.doi.org/10.1111/1467-9450.00194

Son, S., Kim, D.Y., \& Kim, M. (2014). How perceived interpersonal justice relates to job burnout and intention to leave: The role of leader-member exchange and cognition-based trust in leaders. Asian Journal of Social Psychology, 17(1), 12-24. http://dx.doi.org/10.1111/ajsp.12038

Soonhee, K., \& Wright, B.E. (2007). IT employee work exhaustion: Toward an integrated model of antecedents and consequences. Review of Public Personnel Administration, 27(2), 147-170. http://dx.doi.org/10.1177/0734371X06290775

Spreitzer, G., Sutcliffe, K., Dutton, J., Sonenshein, S., \& Grant, A. (2004). Enabling human thriving at work. Ann Arbor: Michigan Business School.

Spreitzer, M.G. (1995). Psychological empowerment in the workplace: Dimensions, measurement and validation. Academy of Management Journal, 38, 1442-1465. $\mathrm{http}: / / \mathrm{dx}$.doi.org/10.2307/256865

SPSS. (2012). SPSS 16.21.0 for Windows. Chicago: SPSS.

Stander, M.W., \& Rothmann, S. (2010). Psychological empowerment of employees in selected organisations in South Africa. South African Journal of Industrial Psychology, 35(1), 1-8.

Steyn, H.S. (2005). Handleiding vir bepaling van effekgrootte-indekse en praktiese betekenisvolheid [Manual for determining effect size indices and practical significance]. Potchefstroom: North-West University Statistical Consultation Services.

Suar, D., Tewari, H.R., \& Chaturbedi, K.R. (2006). Subordinates' perception of leadership styles and their work behaviour. Psychology \& Developing Societies, 18(1), 95-114. http://dx.doi.org/10.1177/097133360501800106

Tabachnick, B.G., \& Fidell, L.S. (2001). Using multivariate statistics (4th edn). Needham Heights: Allyn \& Bacon.

Taplin, I.M., \& Winterton, J. (2007). The importance of management style in labour retention. International Journal of Sociology and Social Policy, 27(1/2), 5-18. http://dx.doi.org/10.1108/01443330710722724

Thomas, K.W., \& Velthouse, B.A. (1990). Cognitive elements of empowerment: An 'interpretive' model of intrinsic task motivation. Academy of Management Review, 15, 666-681. http://dx.doi.org/10.5465/AMR.1990.4310926

Truss, C., Mankin, D., \& Kelliher, C. (2012). Strategic human resource management. Oxford: Oxford University Press.

Tuckey, M.R., Bakker, A.B., \& Dollard, M.F. (2012). Empowering leaders optimize working conditions for engagement: A multilevel study. Journal of Occupational Health Psychology, 17(1), 15-27. http://dx.doi.org/10.1037/a0025942

Van Dierendonck, D., \& Dijkstra, M. (2012). The role of follower in the relationship between empowering leadership and empowerment: A longitudinal investigation. Journal of Applied Social Psychology, 42, 1-22. http://dx.doi.org/10.1111/j.15591816.2012.01022.x 
Van Dijke, M., De Cremer, D., Mayer, D.M., \& Van Quaquebeke, N. (2012). When does procedural fairness promote organizational citizenship behaviour? Integrating empowering leadership types in relational justice models. Organizational Behavior and Human Decision Processes, 117, 235-248. http://dx.doi.org/10.1016/j. obhdp.2011.10.006

Van Dyne L., Graham J.W., \& Dienesch R.M. (1994) Organizational citizenship behavior: Construct redefinition, measurement and validation. Academy of Management Journal, 37, 765-802. http://dx.doi.org/10.2307/256600

Van Schalkwyk, S., Du Toit, D.H., Bothma, A.S., \& Rothmann, S. (2010). Job insecurity, leadership empowerment behaviour, employee engagement and intention to leave in petrochemical laboratory. South African Journal of Human Resource Management, 8(1). http://dx.doi.org/10.4102/sajhrm.v8i1.234

Vecchio, R.P., Justin, J.E., \& Pearce, C.L. (2010). Empowering leadership: An examination of mediating mechanisms within a hierarchical structure. The Leadership Quarterly, 21, 530-542. http://dx.doi.org/10.1016/j.leaqua.2010.03.014
Wilson, G.M., Dejoy, D.M., Vandenberg, R.J., Richardson, H.A., \& McGrath, A.L. (2004). Work characteristics and employee health and well-being: Test of a model of healthy work organization. Journal of Occupational and Organizational Psychology, 77(4), 565-588. http://dx.doi.org/10.1348/ 0963179042596522

Wittig-Berman, U., \& Lang, D. (1990). Individual value systems, organizational investments, and personal constraints as predictors of organizational commitment: Direct or indirect effects? International Journal of Value-Based Management, 3(1) 65-76. http://dx.doi.org/10.1007/BF01560524

Youssef, C.M., \& Luthans, F. (2012). Positive global leadership. Journal of World Business, 47(4), 539-547. http://dx.doi.org/10.1016/j.jwb.2012.01.007

Zhang, X.M., \& Bartol, K.M. (2010). Linking empowering leadership and employee creativity: The influence of psychological empowerment, intrinsic motivation, and creative process engagement. Academy of Management Journal, 53(1), 107-128. http://dx.doi.org/10.5465/AMJ.2010.48037118 